\title{
Biochemical functions of micronutrients
}

\section{Introduction}

Micronutrients are vitamins and minerals required in small amounts that are essential for healthy development and growth. They have great importance for a healthy living. ${ }^{1}$ Micronutrients play a central part in metabolism and in the maintenance of tissue function. ${ }^{2}$

Vitamins are organic substances that function as regulators in the body. They are divided into two groups: fat soluble vitamins (vitamin A, D, E and K) and water soluble vitamins (Vitamin B1, B2, B6, B12, Vit C, Folic acid, etc.). ${ }^{3,4}$. Fat soluble vitamins are stored in the fat tissues and liver, water solube vitamins are found in the aqueous parts of the cells, inside the compartments such as mitochondria which is responsible for oxidation of carbohydrates and fats for energy. ${ }^{5}$ There are many benefits of vitamins and they have a major impact on our overall health.

Minerals are essential nutrients that represent about 5-6\% of the total body weight. There are two major groups of minerals depending on the percentage of body weight and the amount required in diet. Major or macro-minerals are present in the body at levels greater than $0.01 \%$ and they are required in the body in amounts greater than $100 \mathrm{mg} /$ day. They function in both structural and regulatory roles. Some of the major minerals include calcium, phosphorus, sodium, potassium, magnesium and chloride. Trace or micro-minerals are present in the body at levels less than $0.01 \%$ and they are required in amounts less than $50 \mathrm{mg} /$ day, therefore they function primarily in regulatory roles. ${ }^{5}$ Trace elements include iron, cobalt, chromium, copper, fluordie, iodine, manganese, selenium, zinc and molybdenum. They are importantant in many metabolic events and also for healthy immune functions.

Although micronutrients are found naturally in a variety of plant and animal based foods, they can be synthesized in the laboratory that are used in fortified foods. ${ }^{6}$ Micronutrients are important for human body because they are required for vital processes in the human body and their deficiencies can cause serious health problems. ${ }^{7}$

The World Health Organization (WHO) has reported that more than 2 billion people in the world today suffer from micronutrient deficiencies caused largely by dietary deficiencies of vitamins and minerals, primarily iodine, iron, vitamin A, vitamin D and zinc, with important health consequences. ${ }^{8}$ The importance of these deficiencies for the public health lies upon their magnitude and their health consequences, especially in pregnant women and young children, as they might affect fetal and child growth, cognitive development and resistance to infections.

Micronutrient deficiencies are globally important problems which are not always clinically apparent or dependent on food supply and consumption patterns. They might be associated with physiologic effects that can be lifethreatening or more commonly damaging to optimal health and functions of the body. ${ }^{8}$ Iron deficiency is the most prevalent nutrition problem in the world. ${ }^{8}$

Other than a low dietary intake, important causes of maternal near miss (MNM) include poor bioavailability from foods (especially for
Volume 6 Issue 2 - 2017

\author{
Gulcin Sagdicoglu Celep,' Pinar Kaynar,2 \\ Reza Rastmanesh ${ }^{3}$ \\ 'Department of Family and Consumer Sciences Education, Gazi \\ University, Turkey \\ Institution of Public Health of Turkey, Turkey \\ ${ }^{3}$ Nutritionist, Iran
}

Correspondence: Reza Rastmanesh, Nutritionist, Independent Researcher,Tehran, Iran, Email r.rastmanesh@gmail.com

Received: October 28, 2016 | Published: January 27, 2017

minerals), frequent infection with parasites, diarrhea, and various malabsorption disorders. The presence of any of these risk factors can lead to an underestimation of the prevalence of deficiency in a population if this is calculated on the basis of micronutrient intakes alone.

\section{Biochemical functions of micronutrients are reported as follows 9}

1. Cofactors in metabolism-trace elements are frequently involved in modulating enzyme activity or are an integral part of enzyme prosthetic groups.

2. Coenzymes in metabolism-many vitamins or metabolites of vitamins are required to play an active part within complex biochemical reactions. These reactions are critical to intermediary metabolism and ensure utilisation of the major nutrients to provide energy, proteins and nucleic acids.

3. Genetic control-zinc "fingers" are transcription control factors that bind to DNA and regulate transcription of receptors for steroid hormones and other factors.

4. Antioxidants-much of the popular interest in the micronutrients stems from the recognition that many of the micronutrients have antioxidant properties.

Deficiency conditions, their worldwide prevalence and toxicity of some important micronutrients are presented in Table 1.

It was reported that adequate intakes of most micronutrients can be obtained from a typical diet in the UK in adults. ${ }^{10-13}$ Daily recommended intake values for vitamins and minerals for adults are presented in Table $2 \& 3$ respectively.

Clinical benefits can be obtained by supplementation of micronutrients for individuals who are severely depleted however regarding to the micrograms to milligrams ranges of their daily intake values, excess amounts can be even harmful. Consequently, it is recommended to consume micronutrients in proper amounts to balance the adequate levels for optimum health. 
Table I Deficiency conditions, their worldwire prevalence and toxicity of some important micronutrients.

\begin{tabular}{|c|c|c|c|}
\hline Micronutrient & Deficiency & Deficiency prevalence & Toxicity \\
\hline Iron & $\begin{array}{l}\text { Anaemia; low levels of haemoglobin, ferritin reduced learning } \\
\text { and work capacity, increased maternal and infant mortality, } \\
\text { low birth weight }\end{array}$ & 2billion & $\begin{array}{l}\text { Bloody diarrhoea, vomiting, } \\
\text { sometimes liver failure }\end{array}$ \\
\hline Zinc & $\begin{array}{l}\text { Poor growth and sexual maturation, anaemia, enlarged liver } \\
\text { and spleen, skin rash, lethargy pregnancy outcome, impaired } \\
\text { growth (stunting), genetic disorders, decreased resistance to } \\
\text { infectious diseases }\end{array}$ & $\begin{array}{l}\text { Estimated high in developing } \\
\text { countries }\end{array}$ & $\begin{array}{l}\text { Nausea, vomiting, epigastric pain, } \\
\text { abdominal cramps, diarrhoea, } \\
\text { central nervous system deficits, } \\
\text { copper deficiency }\end{array}$ \\
\hline Fluoride & $\begin{array}{l}\text { Mottling of teeth; fluorosis Increased dental decay, affects } \\
\text { bone health }\end{array}$ & Widespread & Excess tooth decay \\
\hline lodine & $\begin{array}{l}\text { Goiter, hypothyroidism, iodine deficiency disorders, increased } \\
\text { risk of stillbirth, birth defects infant mortality, cognitive } \\
\text { impairment }\end{array}$ & 2billion at risk & None \\
\hline Calcium & Decreased bone mineralization, rickets, osteoporosis & $\begin{array}{l}\text { Insufficient data, estimated to } \\
\text { be widespread }\end{array}$ & Rare \\
\hline Selenium & $\begin{array}{l}\text { Fragile red cells; cardiomyopathy, heart and skeletal muscle } \\
\text { degeneration, cardiovascular risk and increased cancer }\end{array}$ & $\begin{array}{l}\text { Insufficient data, common in } \\
\text { Asia, Scandinavia, Siberia }\end{array}$ & $\begin{array}{l}\text { Neuromusculer defects; liver and } \\
\text { muscle damage }\end{array}$ \\
\hline Copper & $\begin{array}{l}\text { Anaemia; poor wound healing; lethargy; depressed collagen } \\
\text { synthesis }\end{array}$ & $\begin{array}{l}\text { Insufficient data, estimated to } \\
\text { be widespread }\end{array}$ & Rare \\
\hline Vitamin A & $\begin{array}{l}\text { Night blindness, xerophthalmia, increased risk of mortality in } \\
\text { children and pregnant women }\end{array}$ & 254million preschool children & Hypervitaminosis $\mathrm{A}$ \\
\hline $\begin{array}{l}\text { Folate (vitamin } \\
\text { B9) }\end{array}$ & $\begin{array}{l}\text { Megaloblastic anemia, neural tube and other birth defects, } \\
\text { heart disease, stroke, impaired cognitive function, depression }\end{array}$ & Insufficient data & Rare \\
\hline $\begin{array}{l}\text { Cobolamine } \\
\text { (vitamin BI2) }\end{array}$ & $\begin{array}{l}\text { Megaloblastic anemia (associated with Helicobacter pylori } \\
\text { induced gastric atrophy }\end{array}$ & Insufficient data & Rare \\
\hline $\begin{array}{l}\text { Thiamine (viamin } \\
\text { BI) }\end{array}$ & $\begin{array}{l}\text { Beriberi (cardiac and neurologic), Wernicke and Korsakov } \\
\text { syndromes (alcoholic confusion and paralysis) }\end{array}$ & $\begin{array}{l}\text { Insufficient data, estimated } \\
\text { as common in developing } \\
\text { countries and in famines, } \\
\text { displaced persons }\end{array}$ & Rare \\
\hline Vitamin D & Rickets, osteomalacia, osteoporosis, colo rectal cancer & $\begin{array}{l}\text { Widespread in all age groups, } \\
\text { low exposure to ultra violet } \\
\text { rays of sun }\end{array}$ & $\begin{array}{l}\text { Bone demineralization, Soft Tissue } \\
\text { Calcifications }\end{array}$ \\
\hline $\begin{array}{l}\text { Vitamin B6 } \\
\text { (pyridoxine) }\end{array}$ & $\begin{array}{l}\text { Dermatitis, neurological disorders, convulsions, anemia, } \\
\text { elevated plasma homocysteine }\end{array}$ & $\begin{array}{l}\text { Insufficient data, estimated } \\
\text { as common in developing } \\
\text { countries and in famines, } \\
\text { displaced persons }\end{array}$ & Rare \\
\hline $\begin{array}{l}\text { Riboflavin } \\
\text { (Vitamin B2) }\end{array}$ & $\begin{array}{l}\text { Non specific - fatigue, eye changes, dermatitis, brain } \\
\text { dysfunction, impaired iron absorption }\end{array}$ & $\begin{array}{l}\text { Insufficient data, est. to } \\
\text { be commonin developing } \\
\text { countries }\end{array}$ & None \\
\hline
\end{tabular}

Table 2 Recommended vitamin intake for adults

\begin{tabular}{lll}
\hline Vitamins & Food sources & Daily Value \\
\hline Thiamin (Vit BI) & Whole grains, seeds, nuts, legumes, fortified foods & $1.1-1.2 \mathrm{mg}$ \\
Riboflavin (Vit B2) & Liver, dairy products, whole grains, leafy greens, meat, eggs & $1.1-1.3 \mathrm{mg}$ \\
Niacin (Vit B3) & Meat, legumes, peanut, can be made from tryptophan & $14-16 \mathrm{mg} \mathrm{NE}$ \\
Pantothenic acid (B5) & Meat, legumes, whole grains, widespread in food & $5 \mathrm{mg}$ \\
Vit B6 & Meat, fish, poultry, legumes, whole grains, nuts, seeds & $1.3-1.7 \mathrm{mg}$ \\
Vit BI2 & Animal products, liver, mussel & $2.4 \mu \mathrm{g}$ \\
Vit C & Citrus fruits, green peppers, strawberries, rosehip, parsley & $75-90 \mathrm{mg}$ \\
Biotin & Liver, egg yolk, synthesized in the gut & $30 \mu \mathrm{\mu g}$ \\
Folic acid & Leafy green vegetables, legumes & $400 \mu \mathrm{\mu g}$ \\
\hline
\end{tabular}


Table Continued....

\begin{tabular}{llc}
\hline Vitamins & Food sources & Daily Value \\
\hline Vit A & Liver, butter, eggs, carrots, leafy greens, cantaloupe & $700-900 \mu g$ \\
Vit D & Egg yolk, liver, tuna, somon, synthesis from sunlight & $5-15 \mu \mathrm{g}$ \\
Vit E & Vegetable oils, leafy greens, seeds, nuts & $15 \mathrm{mg}$ \\
Vit K & Synthesis by intestinal bacteria, vegetable oils, leafy greens & $90-I 20 \mu g$ \\
\hline
\end{tabular}

NF, Niacin equivalent. ${ }^{2,9}$

Table 3 Recommended major minerals intake for adults. ${ }^{2,9}$

\begin{tabular}{|c|c|c|}
\hline Minerals & Food sources & Daily value \\
\hline Sodium & Table salt, processed foods, meat, seafood & $1500 \mathrm{mg}$ \\
\hline Potassium & Fresh fruits, vegetables, potato, banana, meat, nuts, whole grains & $4700 \mathrm{mg}$ \\
\hline Chloride & Table salt, processed foods & $2300 \mathrm{mg}$ \\
\hline Calcium & Milk, cheese, yoghurt, fish, leafy green vegetables, meat & $1000-1200 \mathrm{mg}$ \\
\hline Phosphorus & Meat, liver, diary, cereals, nuts & $700 \mathrm{mg}$ \\
\hline Magnesium & Green vegetables, whole grains, nuts, seeds & $310-420 \mathrm{mg}$ \\
\hline \multicolumn{3}{|c|}{ Trace elements } \\
\hline Iron & Red meat, green vegetables, whole grains, egg yolk, apricot & $8-18 \mathrm{mg}$ \\
\hline Copper & Organ meats, nuts, seafood, cocoa, whole grains, Glycyrrhiza glabra & $900 \mu g$ \\
\hline Zinc & Meat, seafood, oyster, wholegrains, eggs, nuts & 8-IImg \\
\hline Selenium & Organ meats, liver, seafood, eggs, whole grains & $55 \mu g$ \\
\hline lodine & lodized salt, fish, seafood, dairy products & $150 \mu g$ \\
\hline Chromium & Brewers yeast, nuts, whole grains, mushrooms, black pepper & $25-35 \mu g$ \\
\hline Fluoride & Drinking water, tea, fish, toohpastes & $3-4 \mathrm{mg}$ \\
\hline Manganese & Legumes, whole grains, tea, nuts, apricot, coffee & $1.8-2.3 \mathrm{mg}$ \\
\hline Molybdenum & Eggs, organ meat, milk, legumes & $45 \mu g$ \\
\hline
\end{tabular}

\section{Acknowledgements}

None.

\section{Conflict of interest}

The author declares no conflict of interest.

\section{References}

1. Best C, Neufingerl N, Del Rosso JM, et al. Can multi-micronutrient food fortification improve the micronutrient status, growth, health, and cognition of schoolchildren? A systematic review. Nutr Rev. 2011;69(4):186-204.

2. Lori A Smolin, Mary B Grosvenor. Nutrition Science and Applications. 2nd ed. USA: John Wiley and Sons, Wiley; 2010.

3. Butterworth CE , Tamura T. Folic acid safety and toxicity:a brief review. Am J Clin Nutr. 1989;50(2):353-358.

4. Dinçer Y. Vitamins. Ist Uni Cerrahpaşa Medical Faculty, Department of Biochemistry; 2014.
5. Liz Applegate. Nutrition Basics for Better Health and Performance. USA: Kendall/Hunt Publishing Company; 2006.

6. Evaluating the public health significance of micronutrient malnutrition. Guidelines on Food Fortification with Micronutrients. p. 41-92.

7. Fenech MF. Dietary reference values of individual micronutrients and nutriomes for genome damage prevention:current status and a road map to the future. Am J Clin Nutr. 2010;91(5):1438S-1454S.

8. Theodore H, Tulchinsky. Micronutrient Deficiency Conditions:Global Health Issues. Public Health Reviews. 2010;32(1):243-255.

9. Ergin Sencer, Yusuf Orhan. Nutrition Diet. Turkey: Istanbul Medical publishing; 2005.

10. Guidance for Industry. A food labeling guide. USA; 2013.

11. Micronutrient Facts.

12. Shenkin A. Micronutrients in health and disease. Postgrad Med J. 2006;82(971):559-567.

13. Mary B Grosvenor, Lori A Smolin. Nutrition Everyday Choices. 1st ed. USA: John Wiley and Sons, Wiley; 2006. 